\title{
SOCIAL POLICIES IN ITALIAN FASCISM. AUTHORITARIAN STRATEGIES AND SOCIAL INTEGRATION
}

\author{
POLÍTICAS SOCIALES EN LA ITALIA FASCISTA. \\ ESTRATEGIAS AUTORITARIAS E INTEGRACIÓN SOCIAL \\ Chiara Giorgi*
}

\begin{abstract}
The essay will retrace some of the fundamental steps concerning the development of the Italian welfare state during the years of Fascism, framing them within the most recent historiographical debate as well as in the context of some national and international issues. In particular, the national insurance and welfare policies under Fascism will be examined both in the more general context of the growth of social policies seen in the 1930s, and in reference to the main Italian institution responsible for the management of social security (the INFPS, the Fascist National Institute of Social Welfare).
\end{abstract}

KEYWORDS: Fascism, Social policies, Totalitarian State, Social integration, Administration

RESUMEN: El texto desarrolla algunos de los pasos fundamentales relacionados con el desarrollo del Welfare italiano durante los años del fascismo, enmarcándolos tanto en el debate historiográfico más reciente como en el contexto de algunos procesos nacionales e internacionales. As', las pol'ticas sociales fascistas se examinan tanto en el contexto general de extensión de los seguros sociales de la década de 1930, como en lo concerniente a la principal institución italiana responsable de la gestión de estos seguros sociales (el INFPS, -Instituto Nacional Fascista de Previsión Social-).

PALABRAS CLAVE: Fascismo; Pol'ticas Sociales; Estado Totalitario; Integración Social; Administración.

* Correspondence to: Chiara Giorgi. Dipartimento di Ingegneria Civile e Industriale (DICI). Università di Pisa. - Via Girolamo Caruso, 8, 56122 Pisa (Italia) - chiaragiorg@gmail.com- http://orcid.org/0000-0003-0924-1882

How to cite: Giorgi, Chiara (2019). "Social Policies in Italian Fascism. Authoritarian Strategies and Social Integration»; Historia Contemporánea, 61, 907-932. (https://doi.org/10.1387/hc.20259).

Received: 1 October, 2018; Accepted: 4 January, 2019.

ISSN 1130-2402 - eISSN 2340-0277 / (C) 2019 UPV/EHU 


\section{Historiographic premise}

Until the 1980s, historians had a somewhat tentative interest in the social policies Fascism implemented and developed during the 1920s and, above all, the $1930 \mathrm{~s}^{1}$. However, this interest has been growing since the beginning of the new millennium, thanks to contributions that have allowed us to reconsider in more detail the impact the regime had in terms of long-term national social policies ${ }^{2}$.

There have been various factors behind this historiographical change, starting from a more general change in the interpretive lines of Fascism. This has led to a consolidated prejudice that tended to underestimate the impact that was brought about in this area by Fascism being overcome, as its sole aim was the organization of consensus and achieving social control. At the same time, a new awareness of the historical foundations of national 'welfare' has guided historical reconstruction, placing its original characteristics in the very years of the consolidation of the regime.

Since the early 1990s the perception of the centrality of the Fascist experience in relation to the features and dimensions of the Italian welfare state has oriented many reconstructions in the historical field ${ }^{3}$. With respect to this, two further factors have been decisive. One is connected to the 'discovery' of the importance assumed by the Fascist National Party in welfare and social security policies; the other regards the more general debate on the issue of consensus ${ }^{4}$.

This has not only led to the emergence of the fact of the centrality of the Fascist experience, but also that relating to continuity. Thanks to numerous interdisciplinary insights for analysis, historical research has focused on investigating the legacy that the social policies of Fascism has had on the post-World War II welfare 'system', filling a shortfall which,

${ }^{1}$ For a more in-depth analysis see Giorgi, 2012, pp. 55-64; Id., 2014, pp. 93-107.

2 Some of the most significant works published in the 1980s include: Preti, 1980; Id., 1987; Mazzini, 1980; Melis and F. Bonelli, 1989.

${ }_{3}$ Salvati, 1994, p. 24. Some of the most important historical works, or ones that contain precious indications, carried out in the 1990s include: Bonelli, 1993; Preti, 1994; Degl'Innocenti, 1995; Gaeta, 1996; Polsi, 1997; Cherubini, I. Piva, 1998; Girotti, 1998; Sepe, 1999.

4 For critical and problematization considerations regarding consensus see: Corner, 2002; Pergher, Albanese, 2012. 
more generally, Gerhard A. Ritter lamented in the mid-nineties in the premise to the Italian edition of his Storia dello Stato sociale ${ }^{5}$.

In particular, it has been highlighted how the Fascist era laid "the foundations of the 'particularistic-clientelistic' welfare system that would then develop and intensify after the Second World War"' and represent the most distinctive trait of the Italian experience.

Based on the suggestions developed in the field of the social sciences, aimed at making a comparative analysis of the development of welfare in the western world, in the Italian case, Fascism proved to be a decisive moment, aimed at establishing the mould for the subsequent national welfare state. Especially in the 1930s, the considerable expansion of social security - with regard to the extension of the forms of social protection, the number of people covered and especially in terms of the organizational systematization - was pursued by the regime through "a dense regulatory stratification that meticulously differentiated the entitlements of the various groups" $"$. In the Fascist operation of centralizing the administration of social security into three large public bodies (INPS, INAIL, INAM), the trait of differentiation can indeed be recognized as the most prevalent.

Recent research has been increasing in this direction, analyzing the lo$\mathrm{cal} /$ national connections, examining the welfare sector in more depth ${ }^{8}$, focusing on gender issues (especially the role played by women in the various national social policies, the centrality of demographic policies, the strength of familism, and the politicization and professionalization of all those involved in the social security and welfare sphere) $)^{9}$.

\section{Social policies of the 1930s in Europe and United States of America}

On the basis of these premises, this essay will attempt to frame the events pertaining to the Fascist social security policies in the 'great trans-

5 Ritter, 1996.

${ }^{6}$ Ferrera, 1984, p. 36 (own translation). See also Ascoli and Paci, 1984. In addtion, Ferrera, Fargion, Jessoula, 2012.

7 Ferrera, cit. (own translation)

8 See, in particular, Inaudi, 2008; Id., 2010; Catalan, 1992; Vezzosi, 2004; Minesso (edited by), 2007; Bettini, 2008; La banca, 2008; Id., 2014; Id., 2013. See also Vinci (edited by), 2012 .

9 Nunin, Vezzosi (edited by), 2007. See also Vezzosi, 2000, and Id., 2012. 
formation' (as Karl Polanyi put it) of the 1930s, in order to grasp the crisis points of the liberal institutional system and the new strategies adopted to govern society (throughout the world). How, one might ask as a provocation, could Polanyi or Gramsci find similarities between the nascent regimes of Fascism and the New Deal?

As is well known, the Great Depression of 1929 had an enormous impact on the reformulation of the economic and social structure in every national context, especially in relation to the new social policies that were launched by both totalitarian and democratic states. The serious difficulties that struck the market economy led to the problematization, in new terms, of the role of the state in the economic and social life of national communities. As Polanyi himself noted, there was a great similarity between "the emerging regimes of Fascism, Socialism, and the New Deal" ${ }^{10}$, united by their abandoning of laissez-faire principles and their adoption of new social policies.

However, despite the similarities, there were evident differences between the authoritarian-totalitarian Fascist paradigm and the democratic one, both in Europe and in the US (in the two social-democratic and liberal-democratic versions). In short, there was a difference in what Pietro Costa called "direction of the respective "experiments"" 11 . In one case, that of the authoritarian and Fascist contexts, the launch of innovative social policies and new national insurance and social security systems was instrumental to nationalist and imperialist expansion designs, and "to the defence of the racial integrity of the people". In other cases, in the liberal-democratic and social-democratic contexts, it was, at least in theory, supported "by a principle of freedom", capable of using "the interventionist power of the state to support the individual in a process of emancipation" 12 .

In this sense, the attempt to identify common traits in the new approaches that emerged in terms of the social policies and anti-crisis solutions adopted by the various governments can not and must not lead to annulling the differences that even the historiography that is most inclined towards comparative analysis has long recognized.

In Fascist Italy (as in National Socialist Germany) the social policies and social security interventions had the aim of inducing active devotion,

\footnotetext{
10 Polanyi, 1957, p. 252.

11 Costa, 2001, p. 431 (own translation).

12 Ibidem.
} 
capable of absorbing the individual into state institutions and thus superseding the old nineteenth-century authoritarian regimes and eliminating the sphere of individual rights and freedoms ${ }^{13}$.

But it would be useful to start by quickly recalling their common traits. It is in this sense that Gramsci, already a 'witness' of the age, in his Prison Notebooks, provides us with a valid key to interpretation of the similarities between Americanism and Fascism ${ }^{14}$.

According to Gramsci, both tried to respond to the crisis of the liberal system with corporative management of the conflict and the launch of a planned economy. Fascism and Americanism ('the new American industrialism') were characterized by a regressive nature, which did not induce a progressive evolution of the social system in either but, on the contrary, had the function of stabilizing, of remaining anchored to the given structure, challenged by the crisis. However, though Fascism was absolutely regressive, it did introduce more or less profound modifications into the economic structure of post-World War I Italy to accentuate the element of the production plan. So, not a static picture, nor one lacking in rational elements per se, as the social and economic panorama offered by the study of the American phenomenon was neither static nor irrational. A feature common to both phenomena was the constitutive ambivalence to bourgeois modernity, where archaism and innovation coincided. The ambivalence and ambiguity that was typical of modernity and especially of the modernity in the phase of an organic crisis. In both Fascism and Americanism there were rational (progressive) elements that operated within the framework of a social-political phenomenon that had an absolutely regressive nature. The scenario is that of the general crisis of authority that erupted in the post-war period, marked by a crisis of hegemony, or rather by a crisis of the state as a whole. It is here that the crisis of the liberal system left space for the activity of 'dark powers' in Italy represented by providential and charismatic men who directed the process ${ }^{15}$. A common denominator all these dark powers shared was their belonging to the framework of the dominant forces of the old society that was being challenged by the crisis as well as their aversion to the democratic dimension of modernity. The link between these forces and Mussolini's regime was

${ }^{13}$ Mannori, Sordi, 2001, pp. 484-89.

14 Gramsci, 1975, pp. 2139. 2014.

15 Id., Quaderno 13, pp. 1603 and 1619 ff. In regards to this, see Burgio, 2003; Id., 
the basis of the corporatist experiment. It was an exemplary, top-down programme of transformations that were made inevitable by the objective evolution of the material processes. The modifications introduced were therefore governed in order to preserve the essence of the mode of production and of the capitalist social relationship.

In this sense Fascism and Americanism were similar defensive responses to the crisis of the liberal system (in terms of a passive revolution), aimed at the stabilization of a social form that was, by then, without evolutionary potentiality.

Without doubt, other than the differences, which, in any case, Gramsci did not overlook ${ }^{16}$, the comparison between Italy and the United States allows some important elements to be understood into which the events of Fascist welfare may be contextualized. That is, due to the inadequacy of the liberal economic and social policies, a more general propensity to adopt new policies of state intervention, as well as the welfare state of the nineteenth century being superseded.

The very idea of corporatism constituted the most significant point of intersection between the Fascist programmes and those of Roosevelt's America. The propensity towards adopting a system of government based on the "functional coordination of economic interests under state supervision" 17 , in order to achieve a new type of social integration was similar in both cases. The propensity for economic concentration, cartelization, and the medium and long-term financial intervention of the state in the economy through new institutions (the IMI, the Italian IRI, and the American RFC, to name but a few) and the increase of public spending as a brake on the spread of unemployment in the context of large public infrastructure programmes aimed at absorbing the unemployed workforce was also similar in both cases; as was the push to divert public expenditure towards the needs of arms production.

${ }^{16}$ Gramsci himself would, at the same time, recognize differences (unlike Americanism, Fascism established itself by the will of a force, linked to the pre-modern caste order allied with the aforementioned dark forces and the rural bourgeoisie, ready for a war of extermination. It is the moribund old man who does not step back; it is the mix of innovation and archaism).

${ }^{17}$ For a more detailed account see M. Vaudagna, Corporativismo e New Deal. Integrazione e conflitto sociale negli Stati Uniti (1933-1941), Turin, 1981. See also KesslerHarris, M. Vaudagna (ed. by), Democracy and Social Rights in the "Two Wests", Turin 2009 . 
The great depression thus pushed both countries into adopting broader social security systems, despite the substantial difference between the Rooseveltian social policies inspired - at least in theory ${ }^{18}-$ by the universalistic concept of social security, and the very particularistic and categorial Italian ones ${ }^{19}$.

It is possible to find similar trends in the rest of Europe. There was a "recasting bourgeois Europe" which took place under "a decay of parliamentary influence" and of the "evolution toward corporatism". As highlighted by Charles S. Maier, the transition to a system of government that was inclined to seek consensus was achieved in the interwar period "less through the occasional approval of a mass public than through continued bargaining among organized interests" 20 .

It is significant that, this also occurred in the Italian context, where Fascism gave life to forms of realized corporatism, to the extent that it arrived at a "colonization of political decisions [...] by categorial interests" which were directly involved in public offices ${ }^{21}$. It was with these new interests that a mediation strategy became increasingly more necessary, which changed the modalities of national political and institutional governance in a structural sense. The decline of the traditional form of political representation and the eclipse of classic parliamentary representation, the changes taking place in the economy and the overall transformations

18 On the limits of the welfare state in the US, especially in regards to women, see the important volume by T. Skocpol, Protecting Soldiers and Mothers. The Political Origins of Social Policy in the United States, Cambridge 1992.

19 On the New Deal see Katznelson, Fear Itself. The New Deal and the origins of our time, New York, 2013; K. Klaus Patel, The New Deal. A Global History, Princeton NJ 2016; J. Cowie, The Great Exception. The New Deal and the Limits of American Politics, Princeton-Oxford, 2016.

${ }^{20}$ Maier, 1975, pp. 9 ff. As Maier says the recasting bourgeois Europe occurs under a new political economy described as corporatist. "This involved the displacement of power from elected representatives or a career bureaucracy to the major organized forces of European society and economy, sometimes bargaining directly among themselves, sometimes exerting influcence through a weakened parliament, and occasionally seeking advantages through new exectuve authority. In each case corporatism meant the growth of private power and the twilight of sovereignity". For other points of view see Santomassimo, 2006; Stolzi, 2007; Pasetti, 2016. Finally, one aspect of interest is related to the relationships (and the ambiguous attitude, a mixture of admiration and disquiet, towards Fascist corporatism) between the International Labour Organization and Fascism, for which please refer to Gallo, 2013; Id., 2017.

${ }^{21}$ Legnani, 1995, p. 441 (own translation). 
that affected a society in the process of modernization (especially if we consider the redefinition of the relationships between public and private powers), led to a new, networked system of government, based on new forms of consultation between new social components, which, with their own organizations, became progressively more involved in the governing of the country, and, at the same time, able to colonize the overall political decisions with their own categorical petitions. The way in which decisions concerning the national context were made was also new: indeed, they took on the characteristics of a 'negotiation', often not publicized amongst the various actors (the economic-financial elites, senior civil servants, the representatives of the various public bodies, National Fascist Party officials, trade union trustees and the Duce himself). In this general landscape, public bodies would increase in terms of their importance and the number of their functions, moving increasingly into more strategic sectors. They allowed Fascism to recover from the global economic crisis, and, what is more, to become attached to economic and social interests that were previously distant from public policy channels, which, through the public bodies, were then able to find a way to become integrated into the public policies of Fascism. Public bodies were not only confirmed and strengthened as a means of mobilizing and allocating savings, but were used as central institutions for the management of resources and for the strategic direction of economic development (both in the 1930s and in the Republican period).

It is clear that in Italy (as in Germany) the "more or less explicit recasting of the social contract" imposed by the post-war crisis and the one between the end of the 1920s and the beginning of the 1930s was achieved through repression, "the dismantling of the unions and the workers' parties" 22 , and the division of the working class. Nonetheless, the complex practices of governing and social control of Fascist Italy, intended to offer a solution to the crisis already underway, in terms of a rationalization aimed at stabilization, as well as a new national and social integration are far from insignificant.

The 1930s were characterized, albeit in different ways, by the progressive affirmation of modern welfare policies. The advent of the "pluriclass state" (to use the notion of Massimo Severo Giannini), also marked

${ }^{22}$ Girotti, 1996, p. 218, with explicit reference to the analysis of Pierre Rosanvallon (own translation). 
the growth of new administrations, namely those of "social security" and "management of the economy". These administrations were new because the notion that characterized their activities was new. Social security institutes conceived mainly as public charitable institutions already existed in the nineteenth century; however, during the course of the twentieth century, with the "lower classes participating in power", a new notion of social security was reached ${ }^{23}$. In this sense, Giannini explains that, in all countries, with very little variations, the itineraries coincided: that is, there was a move away from forms of assistance that were reserved for certain categories of workers (primarily from industry), and related to some areas, to forms that were increasingly "broader and more comprehensive, in terms of their subjective and objective aspects" 24 . And this was also the case in the contexts where there was an occupational characteristic of the social security and the levels of social benefits were kept low.

The common bases for the subsequent evolution of post-World War II European social policies, centred on the Beveridge model of welfare and on Keynesian demand-management policies, can therefore be said to appear in the 1930s. The problems posed by the ongoing modernization process, and the inadequacy of the liberal solutions that were being proposed, led to the experimentation of solutions that were a far cry from traditional visions. Central to this was the breaking away from free-market orthodoxy and the adoption of policies focusing on a "stimulus of demand through budget deficits", or rather, on a "more drastic form of regulation of the national economy by the state", which later came to be known as Keynesianism ${ }^{25}$. The launch of deficit spending measures, accompanied by broad welfare reforms, provided the necessary conditions for the control of the economic crisis and for the demands of national integration.

As has already been said, there were various outcomes: the model of a particularistic and corporatist welfare state pandering to special interests that emerged in Italy was very different from what arose in Scandinavia. Although there was a common intention to go beyond the nineteenth-cen-

${ }^{23}$ Giannini, 1979, p. 392 (own translation).

24 Ivi, p. 394 (own translation).

25 Gourevitch, 1984, p. 229 (own translation) In general terms in this regard see also Conti, Silei, 2005, pp. $71 \mathrm{ff}$, also refer to this in regard to an up-to-date bibliography of the issue. More generally, among the very large literature on the emergence of different welfare models, see in particular Flora and Heidenheimer, 1983; Esping-Andersen, 1990; Baldwin, 1990; Pierson (ed. by), 2001; Saraceno, 2013. 
tury forms of national insurance and welfare; go beyond the Bismarckian model and that of liberal public assistance.

\section{Social policies during Fascism}

\subsection{Initiatives for pensions and welfare: the role of INFPS}

In this context, the main characteristics of Italian social policies are those that can be traced back to a "particularistic-corporatist", "particularistic-clientelistic" model ${ }^{26}$. Occupational and categorial fragmentation; the correspondence between partial recognition of social security and a total denial of civil and political rights; the permeation of clientelistic logics in the provision of state assistance services were all characteristics.

As in Nazi Germany, there was a strong appeal to people's sense of belonging to a community, as well as to a political movement; to structures of a party and trade union type, which were capable of perfecting the protection of workers outside the field of labour relations.

It is politics that took on a central role in the structuring and management of national social security. In Italy it was the Fascist Party that became the co-manager of social security and welfare measures ${ }^{27}$.

The instrumental use the regime made of social security resources, with a strong emphasis at a propagandistic level, had the aim of consolidating its own power system and hegemonic force, especially in some specific strategic sectors of society ${ }^{28}$. The development in welfare in the years between the two wars, therefore, allowed 'passive' support for the regime to be strengthened in some strata of the national population, towards whom social benefits were instrumentally directed.

The regime put its own stamp on the 'instruments' of social security: on the largest Italian social security institution, the Fascist National Insti-

${ }^{26}$ M. Ferrera, 1984; U. Ascoli, 1984; Gozzini, 2000. The emergence of Italy's pension system shares the broad characterististcs of Italy's welfare model, that is based on occupations, corporatism, fragmentation. However, as argued by Franco Bonelli (1989, p. 133), "an explanation of the characteristics of a pension system can be reached not through a typology [...] of national versions of the welfare state, but rather through the objective analysis of situations resulting from the factors operating in each country at a given time" (own translation)..

27 Pombeni, 1984, p. 261.

28 Corner, 2002. 
tute of Social Welfare (INFPS), and on the agency responsible for managing welfare (EOA), an organ of the National Fascist Party. Welfare, often bordering on charitable aid, was not conceived as a public function, but as an expression of the single party, of the government, which used its own discretion in choosing fields and subjects of action through targeted interventions of a political and clientelistic nature. The very role of welfare towards the most disadvantaged classes should therefore not be overlooked, especially in relation to the penetration of the Fascist Party and its offshoots in the private sphere, and in relation to the possibility the regime had to achieve greater social acceptance deriving from the launch of certain measures in the field of welfare ${ }^{29}$.

It is precisely this instrumental character imprinted on the new national social legislation for the purposes of social control that led to a widespread presence of the single party in the development of the social security and welfare institutions, confirming its fundamental nature as a go-between between citizens and the institutional system in general. If what has just been said is true, that is, that the years of Fascism coincided with the most incisive historical period for the growth of the new social protection administrations, it is not surprising that the INFPS itself was one of the main features of national modernization. The institute indeed represented the reference point for the demand for social security and welfare that was characteristic during the transformations that were taking place in the period between the two wars, an expression of the very development of public social functions.

The great importance assumed by the institute ${ }^{30}$ is, for example, attested by the mere fact that it became, due to its administrative structure and the resources it managed, the largest organism after the state itself. Defined by Mussolini as an "ente fascistissimo" (very Fascist institution), the institute's administrative structure also changed and its activities expanded, under the impetus of goals set from external inputs deriving from the new Fascist social legislation.

29 Inaudi, 2008.

30 Starting out as the National Social Security Fund for old age and disability for the workers (Cassa nazionale di previdenza per la vecchiaia e l'invalidità degli operai) (1898), later becoming the National Social Insurance Fund (Cassa nazionale per le assicurazioni sociali) in the Liberal Age, and thus inherited by the regime, the institution took on this name in the 1930s (1933), remaining as such until today, except for the F for Fascist. 
Thus the Institute, also thanks to an extensive peripheral network, played a fundamental role in Fascist Italy in the construction of a system of articulated control throughout the country. It had a strategic role in the control of the national territory, becoming with its numerous branches one of the regime's biggest systems of administrative communication, and participating both in the construction of gaining consensus for itself and in the policies of social involvement at a local level. Pensions were collected at the Institute's provincial offices, propagandized as the creation of the regime and the Duce; the Institute was involved in the various cultural and social activities of the regime; the Institute participated in significant financial transactions at national level; the Institute owned hospitals and clinics all over the territory that were ready to receive the needy. And, above all, the Institute's actions were subordinate to the needs of the regime, responding to the pressure and requests coming from the party and its provincial federations and letting itself be used, especially in its branches throughout the territory, as a means of social and political control of the periphery of the country ${ }^{31}$. As the most important institution that had to implement social security policies, the INFPS was 'subjugated' by the objectives of Fascist social policies, losing some of its original characteristics that were aimed at protecting the interests of the recipients. The Institute thus ended up losing its autonomy and specific function as a financial institution. The new organizational and financial expansion seen in the 1930s was due to an external impetus with respect to the decisions and initiative of the Institute's management, attesting that the most important body of national social security had then taken an instrumental role within the regime's design of social policy.

An example of this is the 'growth without limits' of the Institute as the director general of INFPS put it - especially since the second half of the thirties. Such growth included a huge expansion of administrative expenditure that increased from 58 to 258 million lire between 1933 and 1941; in 1939 total expenditure on old age pensions was 188 million and outlays for disability were 249 million.

The notes of the director general reveal a concern about the new tasks assigned to the Institute which entailed an increase in expenses, and an attempt to justify this growth with the social values inspiring the activ-

31 In this regard, similar considerations to those in Giorgi, 2012, pp. 131-48 are taken up. Lastly, with particular attention to the role of the Party see Id., 2017. 
ity of INFPS, in obedience "to the directives of the social policy of the Regime" 32 .

In this general transformation, the administrative structure also changed. From the essential and 'light' nature of other public economic and financial institutions, it became a more complex system, similar to that of the civil service.

From a provider of pensions, INFPS became a large body dealing with management and assistance as well as healthcare, having hospitals and clinics , too $^{33}$.

The responsibilities of the Institute increased, as well as the competencies and the power it had to intervene in areas that were often outside of its original mission: for example, real estate, medical-healthcare, and related to the demographic policy of the regime.

After the reforms of 1935, the year in which an important reorganization of social security was launched, a new legislative text emerged that laid out the institution's responsibilities not only in the social security field, but also in the fields of assistance, culture and propaganda. The important aspects at this juncture were the greater centralization of powers in the figure of the president and the director general of the institution, the changing of the men in its upper echelons (more and more homines novi of Fascism) and especially the introduction of new provisions about financial activity, financial statements, and the use of the Institute's funds.

In these years, the INFPS was to implement, as an internal publication has revealed, a growing number of "great socially-inspired initiatives" 34 . Fascism used the Institute's great concentration of social security to fund reclamation work, industrial redevelopment operations, the conquests in Africa, the parcelization of land in the colonies, communications, social housing and so on. Also during the twenty years of Fascism, the Institute gave a strong impetus to its activities in healthcare, promoting the creation of convalescent homes, thermal baths and resorts, widely propagandized by Fascism in every collective demonstration in terms of providential creations of the regime ${ }^{35}$.

In the logic of Fascism to attract ever greater and more strategic social sectors and to make the INFPS an instrument that would be capable

\footnotetext{
32 Relazione del direttore generale, INFPS, Rendiconti, 1937.

${ }^{33}$ For more details see Giorgi, 2004. See also Melis, 1989; Bertini, 2001.

${ }^{34}$ INPS, 1970, p. 256 (own translation).

35 See Pavone, 1993, p. 214.
} 
of strengthening adhesion to the regime, the Institute underwent a process of bureaucratization and unprecedented growth. It lost autonomy and efficiency as a result of taking on more and more management of national insurance. The social security benefits provided were for the most part less than the contributions paid and the Institute's performance became worse and worse, being affected by disadvantageous financial operations that would undermine its original mission as a social insurance provider (as a financing institution, pension provider).

Only in the aftermath of the Second World War, in the face of the inflationary process, when the reserves of the Institute - invested in the great political operations of the regime - suffered severe devaluation, would the result of the Fascist social security policies become clear ${ }^{36}$.

By 1946 nearly sixty different management systems had been entrusted to the INPS; the product of a process that had begun fifteen years before that. Indeed, it is in the 1930s that the Institute expanded beyond measure; taking on a increasing number of insurance operations, employing more and more staff (the number of employees between 1937 and 1941 increased from 6,000 to 8,000 ), accumulating substantial financial assets, providing services (in the period 1920-29, for example, they amounted to only 948 million lire compared to 5,340 billion in revenue, while between 1930 and 1939 there were contributions totalling 11,168 billion lire and 8,971 billion lire was paid out) ${ }^{37}$ and finally being drawn into new activities.

The process of 'bureaucratization' of the Institute became particularly evident in the early forties. The huge assets it possessed became increasingly more likely to be channelled into activities that were dangerous for the quality and level of social security benefits, while making it functional in satisfying the specific political and clientelistic needs of Fascist Italy. Needs which played a major role in structuring the social security system and in the organization of the body appointed to manage it. The Institute found itself facing increasingly more diverse and numerous problems, go-

36 The INFPS, like other social security institutions, was based on financial statements using capitalization, which allowed the immobilization of large economic resources that were "controlled and managed by the State". In this sense, the regime took advantage of the time lapse between the moment the contribution was made and the moment the service was provided in order to use the social security concentration to finance its activities. See Mazzini, 1980, p. 509.

37 Ibidem. 
ing beyond the original social insurance and financial characteristics it had when it was founded.

From a detailed analysis of the INFPS structure two long-term elements of the Italian social security policy emerge: one is the imbalances between the various management structures, which frequently entailed transfers of funds being carried out between the different management structures, with the result that some structures paid for services which should have been paid for by others. The second concerns the blurring of borders between the roles of the Treasury and the management of pensions, insofar as INFPS, instead of using the financial market for its own needs, saw its funds being used directly by the Treasury and in other investment initiatives $^{38}$.

In this context it is clear how the INFPS played a fundamental role in the financing of the State, that is, of Italian public spending between the two wars. The institution freed up, by virtue of using the capitalization system, significant resources for the implementation of infrastructure investments and public housing (either by directly financing works of this kind or through the provision of resources to the state, provinces and municipalities). At the same time it took on the role of being the government's operational arm in financing strategic initiatives ${ }^{39}$. The Institute was thus progressively engaged in an enormous operation of rescue and redetermination of the ownership structure of the Italian economy of the 1930s. Precisely "in the redesigning, in the overtly statist and dirigiste sense, of the [national] industrial and financial system" 40 , the role of the INFS, together with that assumed by Cassa Depositi e Prestiti, became essential. The final balances deserve particular attention as they allow the financial position of this mastodon of social security to be understood.

The three main assets the Institute had on its balance sheet with regard to the management of disability and old age provisions were constituted by state annuities, securities and loans. Overall, the total of op-

38 The Institute thus belonged, along with the INA and the Cassa depositi e prestiti (CDP), to the alternative financial circuit to the Treasury. See Bonelli and Melis, 1989. On the role of public bodies and their centrality in the Italian economy see Cassese, 1985; De Cecco, 1997. For more about public bodies during Fascism see Melis, 1988; Cassese, 2010; Giorgi, 2008; Ferretti, 2014.

39 Beltrametti, Soliani, 2000. For a detailed analysis of financial policies, balance sheets, final balances and personnel policies in the INFPS see Giorgi, 2004.

${ }^{40}$ De Cecco and Toniolo, 2001, p. XL (own translation). 
erating assets rose from 7,783 million in 1933 to $18,658.8$ million in 1941. In terms of unemployment benefits the most significant asset was that corresponding to securities; they followed the sums invested for the various initiatives aimed at combating unemployment through the dual aspect of financial participation and activities carried out directly by the INFPS. The investments for demographic colonization activities undertaken by the Institute in Libya during the 1930s were very important. In addition, the advances to the Colonization Agency of the Apulia of Ethiopia, to the Reclamation Consortium of Burana, had exclusive financial participation. In insurance against tuberculosis, the weight of real estate due to the development of sanitary buildings was considerable. Even in the field of maternity insurance (which later became marriage and birth insurance) the growth of assets was significant, as it was in the field of family allowances. It emerges from the available data that state annuities constituted the most conspicuous item on the Institute's balance sheets throughout the Thirties. This fact takes on particular importance if one considers that this constituted a 'secret' form of financing provided by the INFPS to the state, in that the annuities did not appear as public debt. The latter was therefore much higher than that declared in the official figures, since the "financing of public works and reclamation work had for some time been used to provide for the system of deferred payments, by means of thirty-year annuities payable by the state, which were discounted in some large state and parastatal bodies," like the INFPS "for very large sums at the time." 41 As we have seen, these were "debts paid in instalments arising from the fact that certain payments by the state were divided into annual instalments which were due in years following the one in which the sum ought, as usual, to be extinguished." 42 The aim was precisely that of making the public deficit appear less serious. This practice, already used as an "accounting expedient" for the expenses of the Libyan war ${ }^{43}$, was used even more from the end of 1935 and in connection with the war economy, established starting from the conquest of Ethiopia, up to the years of the world war, with the Spanish civil war and the occupation of Albania in between.

\footnotetext{
${ }^{41}$ Guarnieri, 1988, p. 352 (own translation).

42 Salvemini, Zamagni, 1993, pp. $195 \mathrm{ff}$ (own translation)

${ }^{43}$ For more information see Répaci, 1962, pp. 21, 137, 313; Id., 1934.
} 


\subsection{The peripheral sites of social control}

Analyzing the dynamics in the territory, we find that the peripheral articulation of the INFPS was of great importance in the years between the two world wars, in relation to the control channels of Fascism.

The provincial headquarters of the INFPS played a crucial role in local government contexts and in relation to certain balances of power in towns. It was an important go-between in the management of the country's economic resources, in the operations of offering social advantages the regime had put into practice, becoming the referent of numerous requests for public intervention coming from various national and local contexts. The different subjectivities interested in tapping the flow of resources through the Institute thus strengthening their own power to influence with applications from categories on more complex decisions.

So while universalist welfare systems were being implemented in some European contexts, extended to all citizens, independent of the position held on the market, and of contributory payments, or of employment status, in Italy the measures adopted by Fascism were discretionary, and aimed at individual sectors and categories of workers.

This was closely connected to the fact that the regime played the card of granting certain social benefits (which were however very well defined), against the recognition of political rights. The policies of Fascism were expressed in forms of economic incentives and social safety nets also in order to compensate for the lack of fundamental freedoms. These were also concessions, and sanctioned as such by a state with a totalitarian vocation intent on 'neutralizing' its political opponents, the same social and political conflict and intent to involve certain groups of society that were left relatively out of reach of the state ${ }^{44}$. It was therefore a matter of concessions, and not of conquests linked to citizenship, which can be framed in a government project that aimed at foreshadowing the single but strongly differentiated body of the nation, whose "greater needs" - as one of the many INFPS pamphlets stated - all workers had to obey 45 .

On the other hand, employees were involved in this system because they paid compulsory contributions and not as subjects with rights.

${ }^{44}$ Corner (quoting Tim Mason), 2002, p. 396. See also Id., 2015.
45 INFPS, 1942, p. 10 (own translation). 
However, not all workers had access to social security (labourers and domestic workers were excluded), and they were subjected to a series of rather binding and disciplinary procedures if they applied for it. For example - as Corner noted ${ }^{46}$ - in order to obtain unemployment benefits it was also necessary to pass the scrutiny of committees of specifically competent officials and local potentates, including representatives of the local NFP (National Fascist Party) and the municipal administration. Just as, in addition to presenting a detailed account of the health and financial situation of the whole family of those who requested it, it was also necessary to gain the assent of moralizing and strategic figures: the 'Fascist visitors'. The latter had the task of writing reports on the person or family concerned, which had a significant weight in the decision to grant the social security requested, and above all of a moral and political nature.

With the character of concessions, social security was therefore conditioned by the approval of the regime, by the 'response' of the beneficiaries (in terms of adhesion and integration), by the discretion of the multitude of institutions aimed at dealing with the national insurance, social security and welfare system.

Another significant example is that related to disability pensions. The granting of the pension responded in fact to a logic that was not strictly pertaining to social security, which led the provincial office of the INFPS to unjustifiable pension concessions. In general terms, starting from the 1930s, the number of disability pensions progressively increased compared to the number of old-age pensions, exceeding them at the end of the decade (old-age pensions increased from $0.06 \%$ of GDP in 1930 to $0.08 \%$ in 1939; those for disability increased from $0.03 \%$ to $0.11 \%$ in the same period). In this sense, the disability pension began to assume a different function during Fascism; one that was not directly connected to its original purpose. The great 'popularity' of disability pensions was due to the greater ease with which they could be obtained and the greater indulgence with which they were actually granted, also through the pressure from the federations of the single party (often in contrast to the answers provided

46 Corner, 2002, pp. 398-99. The author explains how the visitors' judgment was binding compared to the possibility for women to access clinics belonging to the Opera nazionale maternità e infanzia. For more on this subject see Saraceno, 1995. As well as Minesso (ed, by), 2007 and more in general see De Grazia, 1993. For another institutional case see Vigilante, 2014. 
at the health level). The analyses conducted at the level of individual citizens attest this dynamic ${ }^{47}$.

Another example is related to social security booklets ${ }^{48}$.

These booklets, proposed by the party in order to avoid duplication, waste, abuse and disorganization, became an important instrument for the party in monitoring the population; an effective instrument for social control; one of the vehicles of political propaganda. The pension itself, rather than being, as it was, the product of the contributions paid in, would be 'disguised' as a prize given directly by and out of the kindness of the Duce.

In all the examples, the access to social security was bound by the opinion of various Fascist authorities or those close to Fascism ${ }^{49}$. The intent was to arrive at a generalized adhesion to the state, while at the same time eluding to the traditional class alignments and referring to that social collaboration, on which the propaganda apparatus of the regime specifically aimed with increasing strength ${ }^{50}$.

It comes as no surprise therefore that, other than the desire to create a public opinion that was in favour of the regime and to soften the effects of the great economic crisis of 1929, the inspiring motives of Fascist social legislation also included one that was functional to the policies of the imperialistic expansion of Fascism ${ }^{51}$.

The most notable consequence of what has been said so far is that the characteristics of national social legislation never reached a universalistic dimension. On the contrary, they gave life to a system resembling a sort of patchwork quilt ${ }^{52}$, in which every single professional category was represented by its own demands. Fragmentation of the subjects invested by social security benefits, particularism, and discrimination were widely prevalent in the social security policies of the regime, who intended above all to protect and attract the closest categories ${ }^{53}$.

Fascism, which would boast of having created one of the most advanced social service systems in Europe, used a system in which the

\footnotetext{
47 For more details about analyses on a territorial level see Giorgi, 2004.

${ }^{48}$ For more details about social security booklets see Corner, 2002.

49 As is rightly observed in Ivi, p. 399.

50 See De Grazia, 1981.

51 Gaeta, 1996, p. 238.

52 See Preti, 2002, p. 695.

53 See Mazzini, 1980, p. 521.
} 
granting of benefits (to employees, and not to citizens) mainly met the criteria of its own political consolidation rather than that of social justice and relieving situations of poverty or need. Fascism would propagandize its achievements in every way possible, as a debt the country had towards its leader; using the assistance programmes for a modern engineering of social control, regulating which beneficiaries to 'admit'.

\section{Conclusions}

Three points emerge. The first is that Italy managed to recover quantitatively compared to the European average, increasing social security spending and the degree of insurance coverage. However, the mould the regime used to shape the national welfare system would influence subsequent developments, bringing out the centrality of the Fascist experience in relation to the characteristics (and dimensions) of the latter.

Secondly, the reorganization that took place in the insurance and social security sphere under Fascism - with regard to the extension of forms of social protection, the number of people covered and especially in terms of systematization - mostly concerned management aspects. The policy of differentiating entitlements was continued and even accentuated and used by the regime to gain social control. Indeed, Fascism multiplied different and differentiated insurance forms and regimens, in terms of breadth, quality and duration.

Finally, the last point concerns the much more complex and ambivalent dynamics regarding the affirmation of the contemporary welfare state.

As has been recently pointed out, "“Welfarist' experiences can not be reconstructed as a 'declension' of a single, compact state entity. If the state is the result of an interweaving of political strategies and power relations and, at the same time, a pawn in socio-political interaction, if it is the moment and vehicle of governmental action, the expression 'Welfare State' refers less to a type or a form of the state, than it evokes a set of practices, knowledge, apparatus and institutions that converge in 'treating' the vital processes of the population" 54 .

54 See Costa, 2017, pp. 72 ff. 
Hence, in more general terms, the opportunity of a methodological perspective - indicated above all by Michel Foucault - capable of reading the dynamics concerning the welfare state, as a "complex and multifaceted object", in the "network of power relations and of subjugation", at the intersection "between 'governamentality' and 'biopolitics", along with all "disciplinary and biopolitical devices". The same links of continuity and discontinuity between nineteenth-century liberalism, successive totalitarianism states and constitutional democracies of the post-war period thus seem illuminated by a reading capable of grasping "the ambiguous intertwining and essential tension between the demands for freedom and the control of 'security' of vital processes" 55 .

\section{Bibliography}

Ascoli, Ugo, (ed. by), Welfare state all'italiana, Laterza, Rome-Bari, 1984 BALdwin, Peter, The Politics of Social Solidarity. Class Bases of the European Welfare States 1975-1975, Cambridge, Cambridge University Press, 1990

BerltrametTi, Luca, Soliani, Riccardo, Alcuni aspetti macroeconomici e redistributivi della gestione del principale ente pensionistico italiano (19191939), Rivista di storia economica, 2, 2000

BERTINI, Fabio, Il fascismo dalle assicurazioni per i lavoratori allo stato sociale, in PALla, Marco (ed. by), Lo Stato fascista, La Nuova Italia, Florence, 2001

BeTtini, Maurizio, Stato e assistenza sociale in Italia. L'Opera nazionale Maternità e Infanzia, 1925-1975, Erasmo, Livorno, 2008

Bonelli, Franco, Appunti sul "Welfare State" in Italia, Studi storici, 2-3, 1993

Bonelli, Franco, L'evoluzione del sistema previdenziale italiano in una visione di lungo periodo in INPS, Novant'anni di previdenza in Italia: culture, politiche, strutture, supplement to no. 1 of Previdenza sociale, Rome, 1989

Burgio, Alberto, Gramsci storico. Una lettura dei «Quaderni del carcere», Laterza, Rome-Bari, 2003

Burgio, Alberto, Gramsci. Il sistema in movimento, DeriveApprodi, Rome, 2014

CASSESE, Sabino, Gli aspetti unitari degli statuti degli enti di Beneduce, in Istituto per la Ricostruzione industriale, Alberto Beneduce e i problemi dell'economia italiana del suo tempo, Edindustria, Rome, 1985

CAssese, Sabino, Lo Stato fascista, Il Mulino, Bologna, 2010

55 Ibidem. 
Catalan, Tullia, Fascismo e politica assistenziale a Trieste. Fondazione e attività dell'Ente Comunale di Assistenza (1937-1943), in VINCI, Anna Maria (ed. by), Trieste in Guerra. Gli anni 1938-1943, Sciarada, Trieste, 1992

CHERUbini, Arnaldo, Piva, Italo, Dalla libertà all'obbligo. La previdenza sociale fra Giolitti e Mussolini, Franco Angeli, Milan, 1998

Conti, Fulvio, Silei, Gianni, Breve storia dello Stato sociale, Carocci, Rome, 2005

CORNER, Paul, Italia fascista. Politica e opinione popolare sotto la dittatura, Carocci, Rome, 2015

CORNER, Paul, Fascismo e controllo sociale, Italia contemporanea, 28, 2002

Costa, Pietro, Lo Stato sociale come problema storiografico, Quaderni fiorentini per la storia del pensiero giuridico moderno, 46, 2017

Costa, Pietro, Civitas, Storia della cittadinanza in Europa. 4. L'età dei totalitarismi e della democrazia, Laterza, Rome-Bari, 2001

CowIE, Jefferson, The Great Exception. The New Deal and the Limits of American Politics, Princeton University Press, Princeton-Oxford, 2016

DE CECCO, Marcello, Splendore e crisi del sistema Beneduce: note sulla struttura finanziaria e industriale dell'Italia dagli anni venti agli anni sessanta, in BARCA, Fabrizio (ed. by), Storia del capitalismo italiano, Donzelli, Rome, 1997

De Cecco, Toniolo, La Cassa Depositi e prestiti nell'economia italiana, 18502000, Laterza, Rome-Bari, 2001

De GraZia, Victoria, Consenso e cultura di massa nell'Italia fascista, Rome-Bari 1981

De GraZia, Victoria, Le donne nel regime fascista, Marsilio, Venice, 1993

DeGL'INNOCENTI, Maurizio, La società unificata. Associazione, sindacato, partito sotto il fascismo, Lacaita, Manduria-Rome-Bari, 1995

EsPing-Andersen, GøstaThe Three Worlds of Welfare Capitalism, Polity Press, Cambridge 1990

FERRERA, Maurizio Il Welfare state in Italia. Sviluppo e crisi in prospettiva comparata, Il Mulino, Bologna, 1984

Ferrera, Maurizio, FARgion, Valeria, Jessoula, Matteo Alle radici del welfare all'italiana. Origini e futuro di un modello sociale squilibrato, Marsilio, Venice, 2012

FERRETTI, Roberto, L'IRI come amministrazione (1933-1945), ISAP, Milan, 2014

Flora, Peter, Alber, Jens (ed. by), Sviluppo dei "welfare states" e processi di modernizzazione e democratizzazione nell'Europa occidentale, in FLORA, Peter, HeIDENHEIMER Joseph (ed. by), Lo sviluppo del welfare state in Europa e in America, Il Mulino, Bologna, 1983

GaEta, Lorenzo L'Italia e lo Stato sociale. Dall'Unità alla seconda guerra mondiale, in G.A. Ritter, Storia dello Stato sociale, Laterza, Rome-Bari, 1996 
GALlo, Stefano, Dictatorship an international organizations. The ILO as a "test ground" for Fascism, in KoтT, Sandrine, Droux, Joelle (ed. by), Globalizing social rights. The ILO and beyond, Palgrave Macmillan, Basingstoke, 2013

GALlo, Stefano, Albert Thomas e il sindacato in Italia. Il Bureau International du Travail, la Confederazione Generale del Lavoro e il corporativismo fascista, Contemporanea, 2, 2017

Giannini, Massimo Severo, I pubblici poteri negli Stati pluriclasse, Rivista trimestrale di diritto pubblico, 2-3, 1979

Giorgi, Chiara, Politiche sociali e fascismo nel dibattito storiografico, in MATTERA, Paolo (ed. by), Momenti di welfare in Italia. Storiografia e percorsi di ricerca, Viella, Rome, 2012

Giongi, Chiara, Die Sozialpolitik der faschistischen Partei in CAvazza, Stefano, Großbölting, Thomas, JANSEN, Christian (ed. by), Massenparteien im 20. Jahrhundert. Christ- und Sozialdemokraten, Kommunisten und Faschisten in Deutschland und Italien, Franz Steiner Verlag, Wiesbaden, 2017

GioRgI, Chiara, Gli enti pubblici di Beneduce nel sistema istituzionale fascista in Melis, Guido (ed. by), Lo Stato negli anni Trenta, Il Mulino, Bologna 2008

GiongI, Chiara, La previdenza del regime. Storia dell'Inps durante il fascismo, Il Mulino, Bologna, 2004.

Giorgi, Chiara, Le politiche sociali del fascismo, Studi storici, 1, 2014

Giorgi, Chiara, The Allure of Welfare State in AlbAnEse, Giulia, PERGHER, Roberta (ed. by), In the Society of Fascists. Acclamation, Acquiescence, and Agency in Mussolini's Italy, Palgrave, New York, 2012

GirotTi, Fiorenzo, Welfare state. Storia, modelli e critica, Carocci, Rome 1998

GoUREVITCH, La rottura con l'ortodossia: un'analisi comparata delle risposte alla Depressione degli anni '30, Stato e mercato, 11, 1984

GozZINI, Giovanni, Povertà e Stato sociale: una proposta interpretativa in chiave di «path dependence», in ZAMAGNI, Vera (ed. by), Povertà e innovazioni istituzionali in Italia. Dal Medioevo ad oggi, Il Mulino, Bologna, 2000

Gramsci, Antonio, Quaderni del carcere, Edizione critica dell'Istituto Gramsci, Einaudi, Turin, 1975

GUARNIERI, Felice, Battaglie economiche tra le due guerre, Il Mulino, Bologna, 1988

I. Katznelson, Ira, Fear Itself. The New Deal and the origins of our time, W. W. Norton \& Company, New York, 2013

Klasu Patel, Kiran, The New Deal. A Global History, Princeton NJ, 2016

Kessker-Harris, Alice, VAudagna, Maurizio (ed. by), Democracy and Social Rights in the "Two Wests", Otto, Turin, 2009

INAUDI, Silvia, A tutti indistintamente: l'Ente opere assistenziali nel periodo fascista, Clueb, Bologna, 2008

INAUDI, Silvia, Strategie politiche e processi di integrazione sociale a Torino negli anni Trenta, Ricerche di storia politica, 3, 2010 
INFPS, Al di là del lavoro e al di là del salario, Rome, 1942,

INPS, Il primo settantennio di attività dell'INPS attraverso la legislazione previdenziale, Roma 1970

LA BANCA, Domenica, Assistenza o beneficenza? La Federazione napoletana dell'ONMI (1926-39), Contemporanea, 1, 2008

La BANCA, Domenica, Il governo dell'assistenza nelle periferie (1925-1945), in GALIMI, Valeria, CoRNer, Paul (ed. by), Il fascismo in provincia. Articolazione e gestioni del potere tra centro e periferia, Viella, Rome, 2014

LA BANCA, Domenica, Welfare in transizione. L'esperienza dell'ONMI (19431950), Edizioni scientifiche italiane, Naples, 2013

LEGNANI, Massimo Sistema di potere fascista, blocco dominante, alleanze sociali, in Del Boca, Angelo, Legnani, Massimo, Rossi, Mario (ed. by), Il regime fascista. Storia e storiografia, Laterza, Rome-Bari, 1995

MAIER, Charles S., Recasting Bourgeois Europe. Stabilization in France, Germany, and Italy in the decade after World War I, Princeton University Press, Princeton, 1975

ManNori, Luca, SoRdi, Bernardo, Storia del diritto amministrativo, Laterza, Rome-Bari, 2001

MAZZINI, Federico, Il sistema previdenziale in Italia fra riforma e conservazione: gli anni della Costituente, in Orsi BatTAGLINI, Andrea (ed. by), Amministrazione pubblica e istituzioni finanziarie fra Assemblea Costituente e politica della ricostruzione, Il Mulino, Bologna, 1980

Mazzini, Federico, Due modelli di amministrazione tra liberalismo e fascismo. Burocrazie tradizionali e nuovi apparati, Ministero per i beni culturali e ambientali.Ufficio centrale per i beni archivistici, Pubblicazioni degli archivi di Stato, Rome, 1988

Minesso, Michela (ed. by), Stato e infanzia nell'Italia contemporanea, Il Mulino, Bologna 2007

Minesso, Michela (ed. by), Stato e infanzia nell'Italia contemporanea. Origini, sviluppo e fine dell'Onmi 1925-1975, Il Mulino, Bologna, 2007

Nunin, Roberta, Vezzosi, Elisabetta (ed. by), Donne e famiglie nei sistemi di welfare. Esperienze nazionali e regionali a confronto, Carocci, Rome, 2007

PACI, Massimo Il sistema di welfare italiano tra tradizione clientelare e prospettive di riforma, in Ascoli (ed. by), Welfare state all'italiana, Laterza, Rome-Bari, 1984.

PASETti, Matteo, L'Europa corporativa. Una storia transnazionale tra le due guerre mondiali, Bononia University Press, Bologna, 2016

PAvone, Claudio, Il regime fascista in La storia. I grandi problemi dal Medioevo all'Età contemporanea, vol. IX. L'età contemporanea. Dal primo al secondo dopoguerra, Garzanti, Milan, 1993

Pergher, Roberta, Albanese, Giulia, Introduction. Historians, Fascism, and Italy Society: Mapping the Limits of Consent, in AlBANESE, PERGHER (ed. by), In the 
Social Policies in Italian Fascism. Authoritarian Strategies and Social Integration

Society of Fascists. Acclamation, Acquiescence, and Agency in Mussolini's Italy, Palgrave, New York, 2012

Pierson, Paul (ed. by), The New Politics of the Welfare State, Oxford, Oxford University Press, 2001

Polanyi, Karl, The Great Transformation. The Political and Economic Origins of Our Time, Beacon Press, Boston, 1957 (first publication: Rinehart \& Company, New York-Toronto, 1944).

Polsi, Alessandro, Amministrazione sociale, Storia, Amministrazione, Costituzione. Annale dell'Istituto per la Scienza dell'Amministrazione Pubblica, 5, 1997

Pombeni, Paolo, Demagogia e tirannide. Uno studio sulla forma partito del fascismo, Il Mulino, Bologna, 1984

Preti, Domenico, Economia e istituzioni nello Stato fascista, Editori Riuniti, Rome, 1980

Preti, Domenico, Il nodo del Welfare State italiano, Italia contemporanea, 194, 1994

PRETI, Domenico, Istituto nazionale fascista per la previdenza sociale (Infps), in De Grazia, Victoria, Luzzatto , Sergio (ed. by), Dizionario del fascismo, vol. I, Einaudi, Turin, 2002

PreTI, Domenico, La modernizzazione corporativa (1922-1940). Economia, salute pubblica, istituzioni e professioni sanitarie, Franco Angeli, Milan, 1987

REPACI, La finanza italiana nel ventennio 1913-1932. La gestione del bilancio, del patrimonio e della tesoreria dello Stato, Einaudi, Turin, 1934

REPACI, La finanza pubblica italiana nel secolo 1861-1960, Zanichelli, Bologna, 1962 ,

Salvati, Mariuccia, Lo Stato sociale in Italia: caratteri originali e motivi di una crisi, Passato e presente, 32, 1994

SALVEMINI, Giancarlo, Zamagni, Vera, Finanza pubblica e indebitamento tra le due guerre mondiali: il finanziamento del settore statale, in COTULA, Franco (ed. by), Problemi di finanza pubblica tra le due guerre. 1919-1939, vol. II, Laterza, Rome-Bari, 1993

Santomassimo, Pasquale, La terza via fascista. Il mito del corporativismo, Carocci, Rome, 2006

SARACEno, Chiara, Costruzione della maternità e della paternità, in DEL BocA, LEGNANI, Rossi (edited by), Il Regime fascista, cit.

SARACENo, Chiara, Il Welfare. Modelli e dilemmi della cittadinanza sociale, il Mulino, Bologna, 2013.

SEPE, Stefano, Le amministrazioni di sicurezza sociale nell'Italia unita (18611998), Giuffrè, Milan, 1999

Stolzi, Irene, L'ordine corporativo. Poteri organizzati e organizzazione del potere nella riflessione giuridica dell'Italia fascista, Giuffrè, Milan, 2007

Vaudagna, Maurizio, Corporativismo e New Deal. Integrazione e conflitto sociale negli Stati Uniti (1933-1941), Rosenberg \& Sellier, Turin, 1981 
Vezzosi, Elisabetta, Maternalism in a Paternalist State: The National Organization for the Protection of Motherhood and Infancy in Fascist Italy in VAN DER KLEIN, Marian et al., Maternalism Reconsidered: Motherhood, Welfare and Social Policy in the Twenty Century, Berghahn Books, New York, 2012

Vezzosi, Elisabetta, Tra vecchio e nuovo: l'Opera Nazionale per la Protezione della Maternità e dell'Infanzia, 1945-1954, in ToninELLI, Pierangelo et al., Trieste Anni Cinquanta. La città reale. Economia, società e vita quotidiana a Trieste, 1945-1954, Comune di Trieste, Trieste, 2004

Vezzosi, Elisabetta, Madri e lavoratrici: l'ONMI nel periodo fascista, in SolDANI, Simonetta, PALAzZI, Maura (ed. by,) Lavoratrici e cittadine nell'Italia contemporanea, Eurocopy, Bologna, 2000

VigIlante, Elena, L'Opera nazionale dopolavoro. Tempo libero dei lavoratori, assistenza e regime fascista 1925-1943, il Mulino, Bologna, 2014

VINCI, Anna Maria (ed. by), Carità pubblica, assistenza sociale e politiche di welfare: Il caso di Trieste, EUT, Trieste, 2012

\section{Datos de la autora}

Chiara Giorgi es profesora asistente en la Universidad de Pisa. Sus principales libros son: La sinistra alla Costituente. Per una storia del dibattito istituzionale (Carocci, 2001); La previdenza del régimen. Storia dell'INPS durante el fascismo (II Mulino, 2004); L'Africa come carriera. Funzioni e funzionari del colonialismo italiano (Carocci, 2012); Un socialista del Novecento. Uguaglianza, libertà e diritti nel percorso di Lelio Basso (Carocci 2015); Costituzione italiana: art. 3 (Carocci, 2017). En la actualidad trabaja con Ilaria Pavan en un proyecto sobre la historia del estado de bienestar italiano. 